\title{
DAMPAK PERNIKAHAN ANAK PADA KEHARMONISAN RUMAH TANGGA DI DESA KANREPIA KECAMATAN TOMBOLO PAO KABUPATEN GOWA
}

\author{
St. Aisyah BM1', Nur Wahidah Mansur ${ }^{2}$ \\ ${ }^{1,2}$ Fakultas Dakwah dan Komunikasi, Universitas Islam Negeri Alauddin Makassar \\ Email: sittiaisyah@uin-alauddin.ac.id ${ }^{1}$,nurwahidahmansur09@gmail.com²
}

\begin{abstract}
Abstrak:
Tujuan penelitian ini yaitu untuk mengetahui bagaimana faktor penyebab terjadinya pernikahan Anak di Desa Kanreapia Kecamatan tombolo Pao Kabupaten Gowa, dan bagaimana dampak pernikahan usia muda pada keharmonisan rumah tangga di Desa tersebut. Jenis penelitian ini adalah penelitian kualitatif dengan pendekatan sosiologi dan kesejahteraan sosial. Sumber data yaitu sumber data primer dan sekunder. Selanjutnya, metode pengumpulan data yang digunakan adalah observasi, wawancara dan dokumentasi. Teknik pengolahan dan analisis data dilakukan melalui empat tahapan, yaitu reduksi data, penyajian data, teknis analisis perbandingan dan penarikan kesimpulan. Hasil penelitian ini menunjukkan bahwa pernikahan anak terjadi disebabkan karena beberapa faktor, yaitu: 1) pendidikan, 2) ekonomi, 3) Budaya. Adapun dampak pernikahan anak terhadap keharmonisan rumaha tangga terdiri atas dampak positi dan negatif, dampak positif berupa memperbaiki silaturahim dan perbaikan ekonomi, sementara dampak negatifnya cenderun terjadinya percekcokan yang berujung pada perceraian. Implikasi dari penelitian ini adalah: Diharapkan perhatian dari pemerintah dalam hal ini DP3A Kabupaten Gowa untuk memberikan arahan kepada perempuan atau anak yang melakukan pernikahan anak, dan upaya pemerintah desa untuk mengembangkan penguatan sumber perlindungan, agar memiliki fikiran untuk tidak menikah di usia anak dalam meningkatkan pola hidup yang lebih baik. Diharapkan bagi para remaja agar mementingkan pendidikan dan juga lebih thebijak dalam mengambil keputusan.
\end{abstract}

Kata Kunci: Dampak Pernikahan, Keharmonisan, Pernikahan Anak

\begin{abstract}
This study was aimed to understand on what factors of child marriage took place in Kanrepia village, Tombolo Pao sub-district, Gowa regency and its effects into family harmony. A qualitative method was the type of this research with sociology and social welfare approach. Data sources were prime and secunder sources. Observation, interview, and documentation were instrument techniques to collect data. The data were analyzed by reducing data, displaying, analysis comparison, and verification or making conclusion. The result of this study indicated that there were three factors of child marriage occurred, namely (1) Education, (2) Economy, and (3) Culture. There were two effects of child marriage. The positive effects were to make social cohesion better and economic improvement. However, the negative effect was about a conflict which ended up by divorcing. This study implicated that the local government by DP3A institution should give some instructions to all adolescent girls to avoid child marriage and facilitate them with knowledge and security instruments, so that they could have a bright mind about it and lift up a better way of life. It was suggested to all young generation to more concern with their education and be wiser to make any decision in their life.
\end{abstract}


Key words: Child Marriage, Harmony, Marriage effect

\section{PENDAHULUAN}

Usia pernikahan yang terlalu muda akan mengakibatkan meningkatnya kasus perceraian karena kurangnya kesadaran suami-istri untuk bertanggung jawab dalam kehidupan berumah tangga tanpa memikirkan akibat dari perbuatan mereka. Pernikahan yang dilakukan pada usia dibawah umur dikhawatirkan akan menghasilkan keturunan yang kurang baik, hal ini bukan saja karena dihasilkan dari bibit yang belum matang, tetapi juga karena kurangnya pengetahuan pasangan muda mudi yang menikah dibawah umur tentang cara-cara pengasuhan anak sehingga anak akan tumbuh dengan pola pengasuhan dan pendidikan yang kurang maksimal selain itu karena mereka masih labil sehingga yang lebih dominan adalah rasa egois . Oleh karena itu, pernikahan yang belum memenuhi syarat usia minimal bolehnya menikah harus diminimalisir untuk mencegah terjadinya perceraian di usian pernikahan yang relative muda.

Pernikahan merupakan perintah agama yang diatur oleh syariat Islam dan merupakan satu-satunya jalan penyaluran seks yang disahkan oleh agama Islam (Atabik \& Mudhiiah, 2014). Menurut Undang-Undang Pokok Perkawinan No.1 Tahun 1974 pasal 1 dijelaskan pernikahan adalah ikatan lahir batin antara seorang laki-laki dengan seorang perempuan sebagai suami istri dengan tujuan membentuk keluarga (rumah tangga) yang Bahagia dan kekal berdasarkan Ketuhanan Yang Maha Esa. Dengan demikian, pernikahan dapat dikatakan sebagai seseuatu yang alami yang menjadi kodrat alam, bahwa dua jenis kelamin yang berbeda akan mempunyai daya tarik antara satu dengan yang lainnya untuk hidup bersama.

Apabila ditinjau dari sudut pandang kedokteran, pernikahan anak mempunyai dampak negatif baik bagi ibu maupun anak yang dilahirkan. Menurut para sosiolog, ditinjau dari sisi sosial, pernikahan anak dapat mengurangi harmonisasi keluarga. Hal ini disebabkan oleh emosi yang masih labil, gejolak darah muda dan cara piker yang belum matang (Puspytasari, 2021). Disisi lain, kematangan fisik seorang wanita terjadi pada usia 20 tahun karena pada usia tersebut alat reproduksi wanita bekerja secara maksimal. Namun, pada 
kenyataannya masih banyak ditemukan pasangan yang melakukan perkawinan saat usianya masih sangat muda di bawah 20 tahun, sehingga dampak negatifnya yaitu resiko kematian bagi ibu dan bayi yang dilahirkan menjadi lebih tinggi. Melihat pernikahan anak dari berbagai aspeknya memang mempunyai dampak negatif. Oleh karena itu, pemerintah hanya mentolerir pernikahan di atas umur 19 tahun untuk laki-laki dan 16 tahun untuk perempuan.

Terdapat perbedaan antara hukum agama dan negara dalam memandang pernikahan dibawah umur (Ali, 2018). Istilah pernikahan anak atau pernikahan dibawah umur menurut negara dibatasi dengan umur. Sementara dalam kacamata agama pernikahan dibawah umur atau pernikahan anak tidak dibatasi oleh usian akan tetapi sangat rawan dengan berbagai masalah yang dapat memengaruhi keharmonisan dalam rumah tangga. Hal ini seiring dengan kurangnya kesiapan fisik, materi, maupun mental pasangan suami istri tersebut. Sebagaimana yang dikemukakan oleh Imeldalius (2017) bahwa kesiapan masing-masing calon mempelai sangat penting dalam membangun sebuah rumah tangga, karena pernikahan adalah bukan sekedar unuk menghalalkan hubungan seksual antara laki-laki dan seorang perempuan, tetapi sekaligus juga merupakan perbuatan hukum keperdataan berupa hak dan kewajiban bagi kedua belah pihak tersebut.

Pada tahun 2016 data yang diperoleh dari Profil Anak Indonesia 2016 menunjukkan persentase anak perempuan yang sudah menikah berusia 10-17 tahun di perkotaan, yaitu 1,02\% sedangkan di daerah pedesaan 2,23\% (Rizali et al., 2018). Pernikahan di bawah umur umumnya terjadi pada mereka yang berusia sama (76\%) antara mempelai laki-laki dan pengantin wanita (Hidayat et al., 2017).

Menentukan batas umur dalam melangsungkan pernikahan sangatlah penting. Ini dimaksudkan agar pernikahan yang dilaksanakan dapat menciptakan keluarga yang sejahtera, bahagia, sehat dan langgeng. Pada dasarnya kematangan jiwa dan fisik seseorang sangat besar artinya untuk memasuki gerbang rumah tangga (Fauzia, 2007). Menurut Saidon et al. (2015) pernikahan di bawah umur memiliki konsekuensi serius terutama pada aspek medis dan psikososial. Orang tua dan keluarga memainkan peran besar dalam menikahkan anak perempuan yang belum cukup umur untuk menikah (Sabbe et al., 2013). Oleh karena itu, pencapaian 
kesejahteraan sebuah keluarga nantinya akan berpengaruh pada tingkat keharmonisan dalam sebuah keluarga.

Tidak sedikit kita membaca berita di media massa mengenai kasus kekerasan dalam rumah tangga. Tidak sedikit kekerasan dalam rumah tangga dialami oleh kaum perempuan, dengan alasan pihak laki-laki merasa stres ataupun kesal dengan hasil jerih payah mereka yang kurang maksimal sehingga tidak mampu membuat keluarga sejahtera lahir dan batin. Dengan demikian, pernikahan yang seharusnya memiliki tujuan membentuk keluarga agar tercapai keluarga yang bahagia dan sejahtera memiliki kemungkinan yang kecil terwujud. Faktor penyebab yang tertinggi adalah ketidak harmonisan. Meskipun ada faktor lain seperti gangguan pihak ketiga, masalah ekonomi, kurangnya tanggung jawab, dan cemburu, namun penyebab yang tertinggi adalah tetap pada ketidak harmonisan keluarga.

Berbagai permasalahan yang dipicu dari keadaan ekonomi dan social pada masyarakat di Desa Kanreapia yang menikah dibawah umur, kesiapan yang kurang matang berpengaruh pada keberlangsungan pernikahan. Pernikahan anak dengan latar belakang pendidikan masih cukup rendah ataupun tidak berpendidikan sama sekali. Sehingga sebagian besar dari mereka kesulitan untuk memeroleh pekerjaan yang di idamkan, padahal sebagai sebuah keluarga terutama untuk kepala keluarga mereka harus memiliki penghasilan yang memadai untuk menghidupi keluarganya. Rendahnya tingkat Pendidikan orang tua, anak dan masyarakat membuat pernikahan anak semakin marak. Wajib belajar 9 tahun bisa dijadikan obat dari fenomena ini, dimisalkan seorang anak bejalar usia 6 tahun, maka saat menyelesaikan study tersebut, dia sudah berusia 15 tahun. Di usia 15 tahun tersebut, seorang anak pastilah memiliki kecerdasan dan tingkat emosi yang sudah mulai stabil. Apalagi bila bisa dilanjutkan hingga wajib belajar tersebut dijalankan dengan baik, maka angka usia pernikahan muda pasti akan berkurang.

Pernikahan anak di Kabupaten Gowa terkhusus Desa Kanreapia terdapat beberapa pasangan melakukan pernikahan dibawah usia 19 tahun. Yang kemudian mengakibatkan banyak hal tang tidak diinginkan bahkan berujung pada perceraian. sementara tujuan dari pernikahan salah satunya mendapatkan ketenangan hati 
sehingga dapat tercapai keluarga yang sakinah mawaddar wa rahmah, hal tersebut tertuang dalam firman Allah QS. Ar-Ruum/30:21

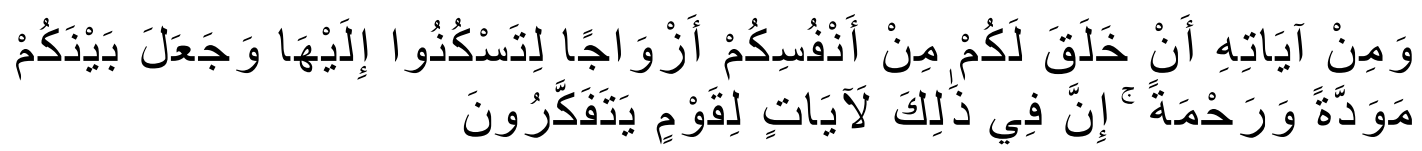

Terjemahnya :

"Dan diantara tanda-tanda kekuasaan-Nya ialah Dia menciptakan untukmu istri-istri dari jenismu sendiri, supaya kamu cenderung dan merasa tenteram kepadanya, dan Dia menjadikan diantara kamu rasa kasih dan sayang. Sungguh pada yang demikian itu benar-benar terdapat tanda-tanda (kebesaran Allah) bagi kaum yang berpikir".(QS: Ar-Ruum ayat 21)

Sehingga dengan demikian pasangan suami istri idealnya harus senatiasa menjaga keharmonsan rumah tanggah, akan tetapi pada kenyataannya masih terdapat beberpa pasangan suami istri yang menikah muda mengalami pertikaian, sekalipun demikian juga terdapat beberapa pasangan yang dapat melanjutkan kehidupan berumahtangga meskipun selalu diwarnai dengan ronah-ronah kehidupan berumah tanggah

Berdasarkan hasil penelitian terdahulu yang telah dilakukan oleh Zulkifli Ahmad (2011) dalam hasil penelitiannya mengemukakan bahwa faktor psikologis yang sangat berpengaruh pada pernikan usia yang relatif muda dan faktor ekonomi yang merupakan dampak secara langsung yang dirasakan oleh masyarakat sebagai pelaku pernikahan usia dini, dan dampak yang paling khas adalah penyesuaian karakter terhadap pasangan masing-masing. Sementara penelitian yang dilakukan oleh Bintang Pratama (2014) menunjukkan bahwa faktor penyebab terjadi pernikahan dini salah satunya adalah Pendidikan, seseorang yang melangsungkan pernikahan ketika baru lulus SMP atau SMA, tentunya berakibat pada sikap egois yg lebih mendominasi. Namun, dari kedua penelitian tersebut belum menyelidiki dampak dari penikahan anak. Oleh karena itu, penulis tertarik untuk melakukan penelitian tentang factor penyebab dan dampak pernikahan anak terhadap keharmonisan rumah tangga di Desa Kanreapia Kecamatan Tombolo Pao Kabupaten Gowa. 


\section{METODE PENELITIAN}

Jenis Penelitian yang digunakan pada penelitian ini yaitu penelitian kualitatif deksriptif, yang mengkaji objek dan mengungkapkan fenomena-fenomena yang ada secara konsepktual melalui pengumpulan data yang diperoleh, dengan melihat unsur-unsur sebagai satuan objek kajian yang saling terikat selanj utnya mendeksripsikannya.

Pendekatan penelitian menggunakan pendekatan sosiologi dan pekerjaan sosial. Pendekatan sosiologi merupakan salah satu ilmu sosial yang banyak mempengaruhi tentang norma sosial dengan keteraturan sosial, bahasan sosiologi lainnya. Pendekatan kesejahteraan sosial dibutuhkan menganalisis masalah sosial yang terjadi dalam kehidupan masyarakat termasuk masalah sosial pernikahan. Analis masalah sosial yang dimaksud yaitu kondisi sosial yang ada di masyarakat, pe rubahan-perubahan sosial yang terjadi, faktor-faktor penyebab terjadinya suatu permasalahan sosial dan bagaimana cara menangani permasalahan sosial tersebut. Dalam menangani permasalahan sosial, tentunya menggunakan praktek pekerjaan sosial yang berlaku dalam upaya memberikan pelayanan sosial yang tepat sasaran (Syamsuddin, 2017).

Sumber data dalam penelitian ini yaitu sumber data primer dan sumber data sekunder. Data primer diambil berdasarkan interaksi langsung di lapangan bersama subyek dan informan dari masyarakat melalui wawancara langsung dengan klien dan observasi langsung masyarakat. Sedangkan data sekunder dikumpulkan untuk melengkapi data primer yang diperoleh dari dokumentasi atau sudah menjadi keputusan yang terkait dengan permasalahan.

Adapun metode pengumplan data yang dipergunakan dalam penelitian ini, yaitu observasi, wawancara, dan dokumentasi. Instrumen penelitian yang digunakan, meliputi pedoman wawancara, alat-alat dokumentasi serta alat tulis. Setelah semua data berupa informasi terkumpul, maka peneliti melakukan analisis data informasi dengan reduksi data (data reduction), penyajian data (data display), dan tahap akhir yaitu penarikan kesimpulan (drawing conclution). 


\section{HASIL DAN DISKUSI}

\section{Gambaran Umum Lokasi Penelitian}

Kanreapia berasal dari dua kata yaitu "Kanre" dan "Api" yang artinya “Terbakar dan Api”. Menurut cerita leluhur orang tua, nama tersebut mulai dikenal saat daerah ini terbakar pada tahun 1921 dan abadi menjadi nama "KANREAPIA" sampai sekarang. Menjadi Desa Persiapan pada Tahun 1985 dan defenitif menjadi Desa Kanreapia pada Tahun 1990. Jumlah penduduk Desa Kanreapia sebanyak 2720 yang terdiri dari Dusun Bontona 1440 jiwa, Dusun Kanreapia 653 jiwa Dusun Silanggaya 627 jiwa. Dari sekian jumlah penduduk berdasarkan profil desa kanreapia salah satu dusun yaitu dususn balang lohe terdapat 14 jumlah KK yang melakukan pernikahan pada usia muda atau pernikahan anak

Tingkat kesejahteraan masyarakat Desa Bonto Marannu masih banyak yang tergolong miskin dari hasil pendataan jumlah Rumah Tangga Miskin mencapai 50\%. Pada sektor pendidikan, pemerintah terus berupaya menyediakan sarana maupun sarana yang memadai serta menyediakan berbagai paket seperti program wajib belajar, pendidikan luar sekolah, sekolah terbuka dan lain-lain. Program ini diharapkan dapat meninkatkan partispasi sekolah, menurunkan jumlah buta huruf, serta meningkatkan pendidikan masyarakat.

\section{Faktor Penyebab terjadinya Pernikahan Anak di Desa Kanreapia} Kecamatan Tombolo Pao Kabupaten Gowa

Pernikahan anak yang terjadi di Desa Kanreapia Kecamatan Tombolo pao itu Kabupaten Gowa berdasar hasil observasi dan wawancara ditemukan bahwa ada beberapa faktor yang menjadi penyebab terjadinya pernikahan anak diantaranya:

\section{Faktor Ekonomi}

Masalah ekonomi merupakan masalah yang paling utama dan terbesar di setiap negara, terutama di negara Indonesia. Indonesia merupakan negara dengan tingkat kemiskinanya sangat tinggi, banyak hal yang menyebabkan terjadinya kemiskinan yang sulit untuk dihilangkan akan tetapi upaya untuk meminimalisir itu tetap dilakukan, begitu banyak cara yang sudah dilakukan untuk mengntisifasi 
akan tetapi kemiskinan malah makin bertambah seiring dengan perubahan dalam pola hidup mayarakat.

Faktor ekonomi menjadi salah satu faktor yang menyebabkan perceraian di Desa kanreapia Kecamatan Tombolopao Kabupaten Gowa, hal itu di uangkapkan oleh ibu Nini adalah perempuan yang usianya 17 tahun pendidikan terakhir SMP dia menikah pada usia 17 sedangkan suaminya berumur 19 tahun.Pasangan ini menikah pada tahun 2020 dan belum di karunia anak pernikahan yang dialami Ibu Nini tak lain disebabkan karena faktor kemauan sendiri. Dan beliau menyatakan bahwa:

"Saya menikah dini karena faktor ekonomi dan kemauan sendiri, dengan menikah dini dapat mengurangi beban orangtua dari permasalahan perekonomian".

Berdasarkan hasil wawancara tersebut diatas dapat dipahami bahwa ternyata persoalan ekonomi adalah faktor yang menyebabkan mereka menikah di usia dini hal itu dikuatkan oleh pernyataan dari ibu Nurti adalah perempuan yang menikah pada usia 14 tahun. pada tahun 2019 Dan pekerjaan sebagai ibu rumah tangga pendidikan terakhir yaitu Sekolah Dasar (SD) menikah Pada usia 14 tahun sedangkan suaminya pendidikan terakhir Sekolah dasar (SD) Bekerja Sebagai petani suaminya berusia 20 tahun, pasangan ini menikah pada tahun 2019 dan ibu nurti dan suaminya masih tinggal di rumah mertuanya selama dia sudah menikah, dan beliau menyatakan bahwa:

"Saya menikah karena faktor ekonomi dan kemauan sendiri,alasan saya untuk menikah mudah untuk mengurangi beban orang tua dan saya juga pacaran sama dia lebih baik menikah muda supaya bisa mengurangi beban orang tua".

Kemudian pernyataan ibu Nurti, dikuatkan lagi oleh pernyataan dari ibu Rahmi adalah perempuan yang menikah pada usia 16 tahun pada Tahun 2020 dan pekerjaan ibu rumah tangga dan pendidikan terakhirnya SMP menikah pada usia 16 tahun sedangkan suaminya pendidikan terakhir Sekolah dasar (SD) pekerjaan suaminya sebagai petani di desa dan usia suaminya 22 tahun pasangan ini menikah pada Tahun 2020 dan selama pernikahan pasangan ini belum di karuniai anak dan beliau menyatakan bahwa: 
"Saya menikah karena faktor ekonomi, dan kemauan sendiri alasan saya untuk menikah muda pada saat itu saya masih duduk di bangku sekolah di smp dan pacar saya datang melamar mau tidak harus diterima karena orang tua saya sudah mau juga, sempat saya menolak menikah muda karena saya masih mau lanjut sekolah tapi orang tua saya mengatakan bahwa saya juga dulu tidak sekolah nak bisa tong ja juga hidup".

Hasil penjelasan di atas, dapat disimpulkan bahwa masalah perekonomian di Desa Kanreapia Kacamatan Tombolopao Kabupaten Gowa menjadi salah satu faktor penyebab terjadinya pernikahan anak dengan alasan dapat meringankan beban orang tua dan menambah penghasilan disebabkan karena ada yang membantu mencari nafkah dan bahkan bisa membantu kedua orang tua untuk membiayai hidu mereka.

\section{Faktor Perjodohan}

Perjodohan diartikan sebagai salah satu ikatan pernikahan, dimana pria dan wanita dipilihkan oleh orang tua, bukan karena pilihan sendiri. Dalam agama Islam Perjodohan merupakan hal yang sah untuk dilakukan, karena bisa menghindari terjadinya hal-hal buruk yang sangat dilarang oleh agama. Faktor perjodohan menjadi salah satu faktor yang menyebabkan pernikahan muda di desa kanreapia Kecamatan Tombolopao Kabupaten Gowa, hal itu di uangkapkan oleh ibu Hasri adalah perempuan yang usianya 17 tahun menikahTahun 2019 Dan pekerjaannya sebagai ibu rumah tangga pendidikan terakhir SMP Sedangan suaminya pendidikan terakhir SMA dan usianya 20 tahun bekerja sebagai petani. Pasangan ini menikah pada tahun 2019 dan pasangan ini masih tinggal di rumah orang tuanya.

"Saya menikah tak lain di sebabkan karena perjodohan, perjodohan ini terjadi di karenakan tidak mampu orang tua saya untuk menyekolahkan, di karenakan harus menjadi ibu rumah tangga sekaligus menjadi tulang punggung keluarga, saya merupakan anak pertama dari 2 bersaudara. Setelah mengetahui bahwa saya telah di jodohkan oleh ibu saya, di dalam benak saya tersimpan ketakutan yang sangat mendalam, saya merasa takut untuk menikah karena trauma dengan rumah tangga orang tua saya, dan saya takut mengalami nasib yang sama dengan orangtua saya".

Demikian halnya juga yang diungkapakan oleh Ani yang menuturkan sebagai berikut: 
"Saya menikah karena kemauan orang tua, lagian yang datang lamarka adalah sepupu dua kali saya, sempat saya menolak pernikahan ini mengingat umur saya masih muda sekali, tapi ini kemauan orang tua, saya harus terimah, kata orang tua saya kenapa kamu tidak mau lagian kamu itu tidak sekolah ji jadi mending menikah mi dari pada jadi perwan tua.dan saya harus terimah semua ini".

Berdasarkan hasil wawancara tersebut di atas maka apat diphami bahwa salah satu faktor penyebab pernikahan anak selain faktor ekonomi adalah faktor perjodohan atau dipasa oleh kedua orang tua yang mau tak mau sang anak harus menjalaninya. Pernikahan anak seperti yang diungkapkan di atas, disebabkan karena dorongan ataupun karena kemauan orang tua yang ingin menikahkan anaknya dengan alasan si anak tidak lanjut sekolah dan takut si anak akhirnya menjadi perawan tua. Berdasarkan hal tersebut, pernikahan dini terjadi karena kemauan orangtua yang ingin menikahkan anaknya di usia dini tanpa memikirkan atau mempertimbangkan usia, pendidikan, kemampuan dan kesiapan si anak untuk membina rumah tangga di usia yang masih muda.

\section{Faktor Pergaulan Bebas}

Pergaulan bebas menjadi salah satu faktor penyebab terjadinya perkawinan anak. Hal ini disebabkan oleh karena beberapa hal diantaranya terlalu cepatnya mereka mengenal handphone yang menyebabkan mereka keseringan menonton hal-hal yang seharusnya belum pantas untuk mereka mengetahui dan mengenal, akan tetapi kemudian mereka secara dini diperkenalkan dengan pergaulan yang mendorong mereka untuk meniru dan kemudian akhirnya melakukan hal-hal yang tidak diinginkan yang keluar dari batas-batas normal layaknya seorang anak diusianya.

Akibat dari perbuatan tersebut yang kemudian mengakibatkan kedua orang tua harus menikahkan mereka sekalipun belum memenuhi syarat undang-undang pernikahan. Kalau pun tidak direstui maka mereka akan menanggung malu dan tidak jarang mereka akan kawin lari.

Demikian halnya yg dituturkan oleh Nurdin selaku imam Desa Kanreapia, "sebahagia anak-anak di sini terlalu bebas bergaul di luar kontrol orang tuanya bersama dengan lawan jenisnya yang kemudian berujung pada 
perbuatan yang tidak senonoh akhirnya mereka harus menikah tanpa melalui

KUA. Tetapi itu hanya sebahagian kecil yang kita temukan di sini."

Berdasarkan hasil wawancara tersebut maka dapat dipahami bahwa salah satu penyebab terjadinya pernikahan dini adalah adanya pergaulan bebas yang kemudian mengakibatkan seorang anak terpancing untuk melakukan perbuatan yang mereka tidak memikirkan dampak atau akibat dari apa yang telah mereka lakukan, semua atas dorongan hawa nafsu dan kebahagiaan sesaat, yang pada akhirnya mereka harus menikah dibawa umur pada usia anak yang kemudian dalam menjalankan rumah tangganya tentu akan lebih dominan muncul keegoisan diantara mereka karena mereka belum matang dalam berfikir dan bertindak, apalagi bila mereka harus memiliki anak dan menjadi bertambah tanggung jawab mereka yang pada dasarnya mereka belum mampu memikul beban itu. Sehingga terjadi sesuatu yg mengakibatkan kehidupan rumah tangga mereka tidak harmonis.

\section{Dampak pernikahan Anak pada keharmonisan rumah tangga}

Bila meliahat beberapa faktor penyebab terjadinya pernikahan anak maka dapat digambarkan kondisi keluarga pasangan pernikahan anak yang tentunya sangat kecil kemungkinan mereka merasakan keharmonisan akan tetapi bukan berarti diantara mereka tidak ada yang merasakan kebahagian, akan tetapi beberap diantara pasangan pernikahan anak ada juga yang merasa harmonis namun kebanyakan yang tidak harmonis. Pertengkaran pasti terjadi namun terkadang para pasangan pernikahan anak ini mampu menyelesaikan masalah dengan baik-baik, namun tidak sedikit juga yang kemudian tidak mampu mengatasinya. dan pasangan yang hendak melangsungkan pernikahan namun usianya belum sampai pada batas yang telah ditetapkan maka orang tua akan tetap menikahkan mereka secara siri atau tanpa mendaftar ke KUA, dan akan kembali melangsungkan pernikahan ketika usia mereka telah sampai batas yang ditentukan dengan mendaftar ke KUA. Seperti yang dikemukakan bapak Nurdin L yang merupakan salah seorang Imam Desa Kanreapia menjelaskan bahwa Pernikahan anak adalah pernikahan yang dilakukan pada usia dibawah 18 tahun untuk perempuan dan 21 tahun untuk laki-laki, akan tetapi terakadang orang tua mereka sudah mau menikahkan anaknya. Beliau menjelaskan bahwa pernikahan anak di 
Desa Kanreapia ini sering terjadi namun tidak tercatat di KUA karena ketika pasangan yang akan menikah namun usianya belum mencapai batas yang ditentukan pemerintah maka orang tua mempelai akan tetap menikahkan dengan cara siri atau tanpa mendaftarkan ke KUA setempat, lalu ketika usia si mempelai telah mencapai usia diperbolehkan menikah maka akan mendaftarkan ke KUA setempat. Dan sampai sekarang masih dilakukan, beliau juga mengungkapkan bahwa mereka harus melakukan pernikahan diusia yang masih belia sehingga tentunya sering terjadi pertengkaran yangdisebakan antara lain: 1) umur yang belum mencukupi, 2) resiko yang akan timbul setelah menikah contohnya: perceraian dini, masalah ekonomi, 3) perbedaan pendapat akibat pemikiran yang belum matang, dan 4) orang tua atau mertua yang menilai menantunya kurang baik. Berdasarkan hal tersebut maka tentunya dalam pernikahan anak terdapat dampak yang berakibat pada keharmonisan keluarga pasangan suami istri yang melakukan pernikahan anak, adapun dampaknya diuraikan sebagai berikut:

\section{Dampak positif pernikahan anak pada Keharmonisan rumah tangga}

Berdasarkan hasil observasi dan wawancara ditemukan bahwa pernikahan anak disamping memiliki dampak negative yang lebih mendominasi juga memiliki dampak positif. Dampak positif dapat tercapai dalam sebuah keluarga yang melakukan pernikahan anak apabila laki-lakinya lebih dewasa, Keharmonisan dalam rumah tangga bersifat relatif. Relatif tersebut tergantung dari pasangan masing-masing yang menjaga hubungan dalam rumah tangga. Rumah tangga yang harmonis yaitu mampu mempertahankan keutuhan keluarganya sampai saat ini, seperti yang kita ketahui terpenuhinya lima aspek: aspek sosial, pendidikan, agama, kesehatan dan ekonomi. Keharmonisan rumah tangga dapat dilihat juga dari sang istri yang mau menerima apa adanya, jika ada permasalahan dapat diselesaikan dengan baik secara kekeluargaan serta dengan didampingi oleh orang tua pasangan menikah muda yang mau memahami kondisi anaknya dan selalu memberi nasehat. Adapun dampak positifnya anatar lain adalah: dapat Menjalin silaturahmi anatara dua keluarga

Dampak positif dalam pernikahan anak dianataranya adalah menjalin silaturahmi antara sesama juga diperlukan, karena sangat berpengaruh agar tali 
persaudaraan semakin erat, dan memperbaiki keharmonisan antara dua belah pihak yang melakukan penikahan anak seperti yang dikatakan oleh ibu Ani.

“Dampak yang saya dapatkan dan keluarga saya yaitu dengan pernikahan ini dapat menyambung silaturahmi antara keluarga saya maupun keluarga suami saya".

Dari hasil wawancara di atas, dapat disimpulkan bahwa dampak positifnya dari pernikahan anak yaitu dapat menciptakan dan menjalin silaturahmi antara dua keluarga yaitu anatara keluarga laki-laki dan keluarga perempuan.

Dampak positif selanjutnya yaitu memperbaiki perekonomian keluarga, dimana saat salah satu pihak keluarga kurang mampu, dan satu pihak keluarga lagi yang sangat berkecukupan, dan anak tersebut dinikahkan maka akan terbantu juga perekonomian pihak keluarga tersebut.

\section{Dampak Negatif pernikahan anak pada Keharmonisan Rumah Tangga}

Selain dampak positif yang telah dikemukankan terdahulu, dampak negative yang senantiasa mendominasi kehidupan keluarga pernikahan anak di Desa Kanreapia. Hal ini terjadi bilamana kedua pasangan sama-sama masih belia, sangat sulit untuk tercapai keharmonisan, karena saling berbeda pendapat, dan emosi yang tidak terkendali. Kemudian kurang terpenuhinya sandang dan papan. Berdasarkan hasil observasi dan wawancara dapat diketahui dampak negatif dari pernikahan anak yaitu:

1. Rentan terjadi Kekerasan dalam Rumah Tangga

Kekerasan dalam rumah tangga (KDRT) tidak hanya di alami oleh pasangan suami istri yang sudah lama menikah, melainkan juga menimpa pada pasangan pernikahan anak, dikarenakan tuntunan hidup yang sulit, seperti yang dialami oleh ibu Rahmi.

"saya pernah dianiaya oleh suami karena pada saat itu saya ingin membeli kebutuhan rumah tangga, namun suami saya menolak karena terlalu mahal, makanya disitu kami bertengkar, dan suami saya sangat emosi dan memukul punggung saya".

2. Perbedaan pendapat 
Perbedaan pendapat juga memicu terjadinya konflik karena egois masingmasing pasangan anak, yang hanya mementingkan pribadi masing-masing, dan kondisi emosi yang belum terkontrol, seperti yang di alami oleh ibu Nurti dan suaminya.

"saya sering marahan, beda pendapat dengan suami saya, karena saya juga sering mementingkan diri saya sendiri, dan suami saya pun juga begitu, biar hanya karena hal yang sepele yang selalu di besar-besarkan".

3. Masalah Ekonomi

Masalah ekonomi merupakan salah satu dampak negative yang sering memicu terjadi pertengkaran, ketika pasangan bersatu dalam ikatan pernikahan. Biasanya masalah ekonomi terjadi apabila sang suami berpenghasilan kecil dan tidak mencukupi kebutuhan hidup dalam rumah tangga, sehingga istri sering kali emosi dan tidak patuh pada suami dan selalu merasa kekurangan seperti yang di alami oleh keluarga ibu Nini "pernah saya menuntut banyak kepada suami saya, tetapi suami saya sudah berusaha untuk memenuhi kebutuhan tersebut, namun saya marah ke dia karena masih banyak kebutuhan hidup yang kurang".

Selain hal tersebut di atas persoalan ekonomi juga menjadi penyebab terjadinya pernikahan anak bilamana orang tua terjebak utang sehingga harus menikahkan anaknya di usia muda, sebagaimana pernyataan salah satu informan.

"Saya menikah muda karena disuru oleh orang tua karena orang tua saya adalah keluarga kurang mampu, dan keluarga suami saya orang mampu, tetapi saya dulu tidak ingin menikah, hanya karena ibu saya telah mengutang sawah dulu dikeluarga suami saya, dan keluarga suami saya meminta membayar utang sawah tersebut dan ibu saya belum bias membayar akhirnya saya di nikahkan oleh anaknya".

Berdasarkan hasil wawancara tersebut dapat diketahui bahwa dampak negative dari pernikahan anak, memicu terjadinya kesalahpahaman anatara kedua pasangan suami istri yang menikah muda yang kemudian berujung pada ketidak harmonisan keluarga yang berakibat pada perceraian yang kemudian merusak hubungan dua keluarga. 


\section{KESIMPULAN}

Berdasarkan hasil penelitian yang telah dikemukakan pada bab sebelumnya, dapat diperoleh beberapa kesimpulan sebagai jawaban atas rumusan masalah, sebagai berikut :

1. Penyebab sehingga terjadinya pernikahan anak di Desa Kanreapia Kecamatan Tombolo Pao Kabupaten Gowa diantaranya: faktor ekonomi, faktor perjodohan, faktor pergaulan bebas.

2. Dampak pernikahan anak pada keharmonisan rumah tangga yaitu: dampak positifnya dapat tercapai apabila laki-lakinya lebih dewasa, keharmonisan dalam rumah tangga bersifat relatif. Relatif tersebut tergantung dari pasangan masing-masing yang menjaga hubungan dalam rumah tangga, sedangkan dampak negatifnya berupa kekerasan dalam rumah tanggan, perbedaan pendapat dan masalah ekonomi yang berujung sampai kepada mengakhiri hubungan pernikahan dengan jalan perceraian.

Hasil penelitian ini menunjukkan beberapa implikasi sebagai berikut:

1. Diharapkan adanya perhatian dari pemerintah dalam hal ini Dinas Pemberdayaan perempuan dan Perlindungan anak Kabupaten Gowa untuk memberikan arahan atau sosialisasi kepada para perempuan atau anak sejak dini sehingga tidak terjadi pernikahan anak.

2. Diharapkan adanya upaya pemerintah desa untuk mengembangkan penguatan sumber perlindungan, agar anak memiliki fikiran untuk tidak menikah di usia anak sehingga bisa melangsungkan kehidupan berumahtangga secara matang dalam meningkatkan pola hidup yang lebih baik, dan

3. Diharapkan bagi para remaja agar melanjutkan pendidikan ke jenjang yang lebih tinggi sehingga bisa berfikir lebih matang demi terciptanya keharmonisan dalam rumah tangga. 


\section{DAFTAR PUSTAKA}

Ahmad, Z. (2011). Dampak Sosial Pernikahan Usia Dini ("Studi Kasus di Desa Gunung Sindur. Bogor"). UIN Syarfi Hidayatullah.

Ali, S. (2018). Perkawinan Usia Muda di Indonesia dalam Perspektif Negara dan Agama serta Permasalahannya (The Teen Marriage In Indonesia On The Country Perspective And Religion As Well As The Problem). 1-28.

Atabik, A., \& Mudhiiah, K. (2014). Pernikahan dan Hikmahnya Perspektif Hukum Islam. Yudisia, 5(2), 293-294.

Fauzia, I. (2007). Dampak Perkawinan dibawah Umur Terhadap Kesejahteraan Keluarga (Studi di Desa Sumberejo Kecamatan Poncokusumo Kabupaten Malang). University of Muhammadiyah Malang.

Hidayat et al. (2017). Politik Pernikahan Dini: Kebijakan Penanganan Di Kalimantan Selatan. BKKBN Provinsi Kalsel.

Imeldalius. (2017). Pelaksanaan Perkawinan Usia Muda dan Pengaruhnya terhadap Perceraian Berdasarkan Undang-Undang Nomor 1 Tahun 1974 Tentang Perkawinan di Kabupaten Indragiri Hulu Tahun 2015. Universitas Islam Riau.

Nguyen, M. C., \& Wodon, Q. (2015). Global and Regional Trends in Child Marriage. Review of Faith and International Affairs, 13(3), 6-11. https://doi.org/10.1080/15570274.2015.1075756

Pratama, B. (2014). Prespekif Remaja Tentang Pernikahan Dini (Studi kasus di SMA Negri 04 Kota Bengkulu”). Universitas Bengkulu.

Puspytasari, H. H. (2021). Perkawinan dibawah Umur Menurut Hukum Islam dan Hukum Positif di Indonesia. Jurnal Jendela Hukum, 8(1), 29-38. https://doi.org/10.24929/fh.v8i1.1332

Rizali, R., Sarman, M., \& Hidayat, T. (2018). Underage Marriage Cases and Their Implications on Economic Stability Households in The District of Kandangan, Hulu Sungai Selatan, Indonesia. European Journal Of Social Sciences Studies, 3(4), 123-136. https://doi.org/dx.doi.org/10.46827/ejsss.v0i0.478

Sabbe, A., Oulami, H., Zekraoui, W., Hikmat, H., Temmerman, M., \& Leye, E. (2013). Determinants of child and forced marriage in Morocco: Stakeholder perspectives on health, policies and human rights. BMC International Health 
and Human Rights, 13(1). https://doi.org/10.1186/1472-698X-13-43

Saidon, R., Adil, M. A. M., Sahari, N. H., Sahri, M., Alias, B., Daud, N. M., \& Murad, K. (2015). Developing a New Model of Underage Marriage Governance for Muslims in Malaysia. Middle-East Journal of Scientific Research, 23(4), 638646.

Syamsuddin. (2017). Dasar-dasar Teori Metode Penelitian Sosial Cet. I. Wade Group. 